\title{
Pengaruh Loneliness terhadap Job Stress Pekerja Work from Home (WFH) pada Masa Pandemi Covid-19
}

\author{
SEPTA AYU TRISNASARI \& DIMAS ARYO WICAKSONO* \\ Fakultas Psikologi Universitas Airlangga
}

\begin{abstract}
ABSTRAK
Penelitian ini bertujuan untuk mengetahui pengaruh loneliness terhadap job stress pekerja selama work from home (WFH) di masa pandemi Covid-19. Dampak negatif WFH salah satunya telah mengubah budaya kerja Indonesia yaitu bekerja secara kolektif dialihkan menjadi bekerja mandiri dan sedikitnya pekerjaan yang dilakukan secara kolektif. Hal ini mengarahkan adanya bekerja kesepian dengan isolasi emosional dan tuntutan bekerja sendirian atau secara individu yang mengarahkan adanya stress kerja dikarenakan adanya beban kerja atau tuntutan pekerjaan yang harus diselseikan secara mandiri. Hipotesis penelitian ini adalah terdapat pengaruh loneliness terhadap job stress pekerja selama WFH. Penelitian ini menggunakan pendekatan kuantitatif. Pengumpulan data menggunakan alat ukur kesepian UCLA dan Job stress. Kuesioner diberikan pada 107 pekerja WFH. Analisis data menggunakan Uji Regresi Linear Sederhana dengan hasil penelitian Sig. 0,034 yang berarti terdapat pengaruh loneliness terhadap job stress pekerja selama WFH. Oleh karena itu dapat disimpulkan adanya pengaruh positif loneliness terhadap job stress pekerja selama WFH.
\end{abstract}

Kata kunci: covid-19, kesepian, stress kerja, wfh

\section{ABSTRACT}

This study aims to determine the impact of loneliness on the job stress of employee during work from home (WFH) in the Covid-19 pandemic. One of the negative impacts of WFH is changing Indonesia's work culture, working collectively which change to working independently. This leads to lonely work with emotional isolation and the demands of working alone which leading to work stress due to work demands that must be resolved independently. The hypothesis is that an impact of loneliness on the job stress of employee during WFH. This study uses a quantitative approach. Collecting data using the UCLA loneliness scale and Job stress. A questionnaire was given to 107 WFH. Analysis using Regression Test. The results of Sig. 0,034, there is an impact of loneliness on the job stress. It can be concluded that there is a positive impact of loneliness on the job stress of employee during WFH.

Keywords: covid-19, job stress, loneliness, wfh

Buletin Penelitian Psikologi dan Kesehatan Mental (BRPKM), 2021, Vol. 1(2), 1218-1226

*Alamat korespondensi: Fakultas Psikologi Universitas Airlangga, Kampus B Universitas Airlangga Jalan Airlangga 4-6 Surabaya 60286. Surel: aryo.wicaksono@psikologi.unair.ac.id

Naskah ini merupakan naskah dengan akses terbuka dibawah ketentuan the Creative Common Attribution License (CC-BY-4.0) (http://creativecommons.org/licenses/by/4.0), sehingga penggunaan, distribusi, reproduksi dalam media apapun atas artikel ini tidak dibatasi, selama sumber aslinya disitir dengan baik. 


\section{PENDAHULUAN}

Dampak Covid-19 salah satunya perubahan yang muncul dalam "tempat kerja" yang dimana Covid-19 tiba-tiba mengubah rutinitas kerja normal yang menyebabkan percepatan tren yang sudah berlangsung dan melibatkan migrasi pekerjaan ke online atau work from home (WFH). WFH adalah pengaturan kerja dimana seorang pekerja memenuhi tanggung jawab penting dari pekerjaannya dengan tetap dirumah, dan menggunakan teknologi informasi dan komunikasi atau (ICT). Bekerja dari rumah atau Work from Home (WFH) di Indonesia berdasarkan data Badan Pusat Statistik Per 7-14 September 2020 sebanyak $62 \%$ dari total responden mengaku tempat kerjanya menerapkan WFH. Perubahan dramatis ini dalam praktik kerja cenderung memiliki sejumlah dampak bagi karyawan (Kniffin dkk., 2021), beberapa positif beberapa negatif. Beberapa perubahan positif dalam jurnal (Nakrošienė dkk., 2019) diantaranya kebebasan pengaturan waktu seperti penjadwalan yang lebih fleksibel daripada bekerja di kantor, karyawan dapat bekerja di jam produktif mereka bahkan di malam hari, meningkatkan autonomi, mengurangi komunikasi informal, meningkatkan waktu luang dengan keluarga, mengurangi perjalanan dan biaya bepergian, meningkatkan kesempatan untuk perempuan yang memiliki anak, siswa dan orang disabilitas, mengurangi kemacetan dan polusi udara. Sedangkan dampak negatif WFH salah satunya Berdasarkan jurnal penelitian (Mustajab dkk., 2020) WFH telah mengubah budaya kerja sebagian besar organisasi di Indonesia selama penyebaran Covid-19.

Budaya kerja di Indonesia salah satunya adalah kolektivitas atau bekerja secara kolektif, dan orang Indonesia lebih kecil kemungkinannya untuk mendukung individualisme, dan dikatakan bahwa budaya kolektif mendominasi Asia Timur, Amerika Latin, dan Afrika (Ramesh \& Gelfand, 2010). Work From Home ditengah masa pandemi Covid mengarahkan isolasi diri atau isolasi sosial untuk mengurangi aktifitas diluar rumah dan bertemu dengan orang lain atau melakukan kontak fisik dengan rekan kerja untuk mencegah penyebaran Covid-19. Hal ini telah membuat banyak pekerjaan mungkin dilakukan lebih mandiri dan menyebabkan sedikitnya pekerjaan yang dilakukan secara tim atau kolektif (Pinar, 2014). Sedikitnya pekerjaan yang dapat dilakukan secara tim atau kolektif mengarahkan perilaku kolektif seseorang berkurang dan mengarah pada individualisme dalam menyeleseikan tugas-tugas pekerjaannya.

Budaya kolektif "memiliki harapan yang lebih tinggi terhadap interaksi sosial dan karenanya akan merasakan diri mereka sendiri menjadi lebih kesepian jika harapan ini tidak terpenuhi" (Sonderby \& Wagoner, 2013). Sedangkan individualis memiliki harapan yang lebih rendah untuk interaksi sosial dan akan merasakan lebih sedikit kesepian (Lykes \& Kemmelmeier, 2014). Ditemukan penelitian dari Lykes \& Kemmelmeier (2014), bahwa masyarakat kolektivis merasa menjadi lebih kesepian. Dikarenakan budaya Indonesia adalah kolektivis, dengan adanya isolasi sosial maka akan mengarahkan dengan adanya kesepian karena perubahan sistem kerja yang mandiri dan sedikitnya pekerjaan yang dilakukan secara tim atau kolektif. Dikarenakan tingginya harapan kelompok kolektivis terhadap interaksi sosial, maka apabila hal ini tidak dapat dipenuhi atau berkurang maka seseorang akan mengalami kesepian.

Ketika budaya kolektivis merupakan budaya bekerja di Indonesia yang dimana banyaknya tugas atau pekerjaan terbiasa dilakukan dengan tim ataupun secara kolektif tidak dapat dilakukan lagi, dikarenakan adanya peraturan WFH yang dimana tugas pekerjaan harus diselesaikan secara mandiri atau secara individu selama periode pandemi, dapat memunculkan adanya perasaan sendirian atau bekerja sendiri yang dapat mengarahkan pada perasaan kesepian, dan tuntutan untuk bekerja atau menyelesaikan tugas pekerjaan sendiri atau secara individu dapat mengarahkan adanya stress kerja atau job stress dikarenakan adanya beban kerja atau tuntutan pekerjaan yang harus diselseikan secara mandiri. Selain itu stress kerja di Indonesia menjadi masalah serius yang mengakibatkan angka gangguan mental emosional sebesar 9,8\% dan sebesar 35\% stress akibat kerja berakibat fatal,

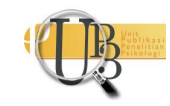


diperkirakan hari kerja yang hilang sebesar 43\%. Dengan adanya perubahan sistem WFH pegawai merasa tertekan dan memiliki beban kerja berlebih terhadap penyesuaian perubahan sistem kerja seperti Guru yang harus merubah sistem pembelajaran di sekolah menjadi WFH akibat Covid-19 (Azhar, 2021).

Selain itu penelitian dari jurnal yang ditulis oleh Kaymaz dkk. (2014), mengenai effect of loneliness at work on the Employees Intention to Leave, yang menemukan hasil bahwa loneliness berpengaruh pada keinginan karyawan untuk pergi atau employees' intention to leave. Dijelaskan bahwa hal ini menunjukkan loneliness atau kesepian dapat menyebabkan stress kerja, komitmen organisasi yang lemah dan masalah dalam hubungan sosial yang akhirnya dapat memicu keinginan untuk meninggalkan organisasi.

Berdasarkan latar belakang diatas, maka rumusan masalah untuk penelitian ini yaitu "Apakah terdapat pengaruh loneliness terhadap job stress selama work from home pada pekerja di masa pandemi covid19?". $\mathrm{H}_{\text {a }}$ pada penelitian ini adalah adanya pengaruh loneliness terhadap job stress pekerja selama WFH dimasa pandemi Covid-19. Tujuan pada penelitian ini adalah untuk mengetahui apakah terdapat pengaruh loneliness terhadap job stress pekerja selama WFH dimasa pandemi Covid-19. Dan apabila terdapat pengaruh selanjutnya adalah untuk mengetahui dimensi-dimensi apa saja yang dapat berpengaruh.

\section{LONELINESS}

Kesepian didefiniskan sebagai kurangnya ikatan sosial yang dirasakan atau perasaan subjektif seseorang tentang kurangnya ikatan sosial, yaitu adanya perbedaan secara objektif (sendirian) dan subjektif (perasaan sendirian) (Weiss, 1973). Ikatan sosial sendiri jelas dipengaruhi oleh kekuatan sosial. Sebagai contoh individualisme pada masyarakat kolektivis dapat meningkatkan kesepian seseorang melalui pekerjaan atau tugas-tugasnya yang diselseikan secara mandiri, seperti peningkatan fokus karir, menunda atau melepaskan hubungan dengan keluarga sehingga meningkatkan isolasi sosial. Terdapat dua dimensi kesepian menurut Weiss (1973), yaitu isolasi emosional dan isolasi sosial. Isolasi emosional yang merupakan ketidakhadiran yang dirasakan dari kedekatan emosional, sedangkan isolasi sosial dihasilkan dari isolasi relasional yaitu tidak adanya hubungan integratif sosial atau jejaring sosial yang menarik. Kesepian dihasilkan dari sebuah celah antara keadaan ideal dan aktual dari hubungan sosial yang dekat atau karena sifatnya yang relasional, kesepian kerja dikaitkan dengan cara karyawan mencari koneksi dengan orang lain ketika mereka merasa kehilangan hubungan dekat (Ozcelik dkk., n.d.). Kesepian juga diartikan sebagai emosi yang diakibatkan oleh perasaan subjektif orang-orang bahwa kebutuhan intim dan sosial mereka tidak terpenuhi secara memadai dan sudah dianggap sebagai epidemi sebelum covid-19 (Cacioppo dkk., 2006).

\section{JOB STRESS}

Job stress atau stres kerja merupakan kombinasi dari pengalaman kognitif stress dalam konteks pekerjaan dan pengalaman tuntutan terkait pekerjaan. Sedangkan menurut Cullen dkk. (1985), stres kerja adalah suatu keadaan dimana terdapat ketidaknyamanan psikologis maupun ketegangan yang dapat mengarahkan adanya stressor. Pada job stress menurut Cullen dkk. (1985) terdapat dimensi anxious, angry, upset. Job stress juga diartikan sebagai kesadaran individu atau perasaan disfungsi personal sebagai akibat dari kondisi yang dirasakan atau sebuah peristiwa di tempat kerja (Parker \& DeCotiis, 1983).

Faktor yang dapat menimbulkan stress kerja, yaitu tuntutan pekerjaan, dukungan sosial, hubungan interpersonal, dan perubahan pada organisasi. Setiap orang pasti memiliki pemikiran dan cara pandang 
yang berbeda oleh karenanya dapat dikatakan bahwa perbedaan pendapat dan penilaian setiap orang serta proses psikologis untuk dapat menerima tuntutan sekitarnya sebagai nilai suatu hal yang baik atau buruk, jika penilaian akhir adalah suatu hal yang buruk maka hal tersebut dapat mengarahkan pada job stress (Rizkiyani \& Saragih, 2012). Pekerja yang mengalami stress dapat menyebabkan tidak aman, tidak menyenangkan, dan fasilitas umum yang tidak berjalan dengan baik. Selain itu job stress juga dikaitkan dengan kematian dini, fisik dan masalah kesehatan mental, penyakit masalah sosial, dan penurunan kinerja pekerjaan. Selain itu dampak negatif job stress dapat menimbulkan konflik dengan teman maupun keluarga, penurunan produktivitas, penggunaan obat-obatan, turnover.

\section{Desain Penelitian}

\section{METODE}

Model yang digunakan adalah metode pendekatan kuantitatif-eksplanatori dengan desain crosssectional. Metode pendekatan kuantitatif-eksplanatori dapat digunakan untuk mengukur atau menguji hubungan sebab-akibat dari dua atau lebih variabel. Pengumpulan data yang digunakan adalah data primer yang langsung didapatkan dari responden dengan menyebarkan kuesioner secara online melalui Google Form.

\section{Partisipan}

Dalam penelitian ini kriteria partisipan yang diambil sampelnya adalah karyawan yang pernah atau sedang melakukan WFH (Work from Home) di masa pandemi Covid-19. Penelitian ini menggunakan teknik sampling yaitu non-probability sampling dengan metode accidental sampling. Dalam penelitian ini didapatkan jumlah sampel partisipan yang diambil dan dipilih berdasarkan penghitungan menggunakan aplikasi G*Power 3.1. Pengambilan data diawali dengan informed consent yang menyatakan partisipan bersedia berpartisipasi dalam penelitian ini.

Keseluruhan jumlah partisipan yang didapatkan dalam penelitian ini sebanyak 107 orang dengan $\left(M_{\text {usia }}=17 ; S D_{\text {usia }}=38 ; 66,4 \%\right.$ perempuan $)$. Latar belakang pendidikan sebagian besar partisipan yaitu akhir S1 dengan presentase 80,4\% dan status pernikahan sebagian besar belum menikah, dengan presentase sebesar 91\%. Jenis pekerjaan partisipan di bidang usaha jasa, yaitu sebesar 37,4\% dengan level jabatan sebagai staff sebanyak 76,6\%.

\section{Pengukuran}

Penelitian ini memiliki satu variabel independen dan satu variabel depeden. Variabel independen yang digunakan yaitu loneliness, sementara variabel dependen yang digunakan yaitu job stress. Pengukuran pada penelitian ini menggunakan dua instrumen, antara lain yang pertama, yaitu UCLA (University of California Los Angeles) Loneliness Scale Version 3 yang dikembangkan oleh Russell (1996) yang diadaptasi oleh peneliti. Instrument kedua, yaitu job stress scale (JSS) diadaptasi dari Cullen dkk. (1985) untuk mengukur stres kerja yang terdiri atas dimensi anxious, angry, upset.

Kedua instrumen tersebut menggunakan skala Likert yang dimana semakin tinggi skor yang didapatkan maka akan menunjukkan dukungan yang lebih besar terhadap variabel tersebut. UCLA Loneliness Scale Version 3 terdiri dari 20 aitem dengan 4 pilihan jawaban (1= "tidak pernah", 4=" selalu"), dengan koefisien reliabilitas 0.941. sedangkan alat ukur JSS terdiri dari 6 aitem dengan 7 pilihan jawaban (1= "sangat setuju sekali", 7= "sangat tidak setuju sekali") dengan koefisien reliabilitas 0.898. 


\section{Analisis Data}

Analisis data penelitian ini menggunakan teknik regresi linear sederhana. Teknik regresi linear sederhana dilakukan untuk mengetahui adanya pengaruh atau tidak pada satu variabel independen terhadap variabel dependen. Uji regresi linear sederhana dapat dilakukan apabila telah memenuhi uji asumsi yang terdiri dari uji normalitas, uji linearitas, uji heterokedastisitas, dan uji korelasi, untuk itu penulis telah melakukan uji asumsi terlebih dahulu agar dapat dilakukan uji regresi linear sederhana. Penulis menggunakan aplikasi IBM SPSS Statistic 20 for Windows.

\section{HASIL PENELITIAN}

\section{Analisis Deskriptif}

Analisis deskriptif dilakukan penulis agar dapat mendeskripsikan atau menggambarkan statistik data yang telah terkumpul. Pada variabel loneliness ditemukan nilai mean sebesar 59,50 (SD=8,224; Min=35; Max=72), hal ini menunjukkan rata-rata partisipan merasa cukup kesepian atau memiliki tingkat kesepian yang sedang. Selanjutnya pada variabel stres kerja ditemukan mean sebesar 25.29 (SD=7,130; Min=8; Max=42) menunjukkan rata-rata kecenderungan partisipan memiliki tingkat stres kerja yang sedang.

\section{Analisis Regresi}

Dalam penelitian ini digunakan analisis regresi sederhana untuk melihat pengaruh loneliness terhadap job stress, model ini cocok untuk menjelaskan data. Diketahui bahwa variabel independen memiliki pengaruh terhadap job stress $\left(F=4.611 ; p=0,034 ; R^{2}=0,042\right)$ serta varians dari loneliness dapat menjelaskan 4,2 persen terhadap job stress. Maka dapat disimpulkan bahwa loneliness memiliki pengaruh yang signifikan terhadap job stress sebesar 4,2 persen. Selanjutnya hasil uji korelasi pearson diketahui loneliness $(B=0,178 ; S E=0,083 ; t=2,147 ; p=0,034)$ berkorelasi positif dalam menjelaskan $j o b$ stress, dengan apabila loneliness meningkat maka akan terjadi peningkatan job stress sebesar 0,178. Maka dapat disimpulkan bahwa loneliness secara parsial berpengaruh positif terhadap Job stress.

Selanjutnya Untuk mengetahui pengaruh masing-masing dimensi variabel loneliness terhadap job stress maka penulis melakukan analisis regresi linear sederhana pada masing-masing dimensi tersebut. Diketahui hasil menunjukkan dimensi isolasi emosional memiliki nilai yaitu $(B=0,429 ; S E=0,161$; $t=2,666 ; p=0,009$ ) berkorelasi positif dalam menjelaskan job stress. Sedangkan pada dimensi isolasi sosial $(B=-0,191 ; S E=0,142 ; t=-1,345 ; p=0,181)$ berkorelasi negatif terhadap job stress. sehingga, dapat diartikan bahwa hanya dimensi isolasi emosional yang memiliki pengaruh secara signifikan terhadap job stress dikarenakan memiliki nilai signifikansi probabilitas kurang dari 0,05, sedangkan dimensi isolasi sosial sama sekali tidak berpengaruh secara signifikan karena memiliki nilai probabilitas diatas 0,05 yaitu sebesar 0,181 .

\section{DISKUSI}

Penelitian ini bertujuan untuk mengetahui apakah terdapat pengaruh loneliness terhadap job stress pekerja selama WFH di masa pandemi Covid-19. Berdasarkan serangkaian analisis yang telah dilakukan, ditemukan hasil bahwa variabel independen memiliki pengaruh terhadap job stress dengan

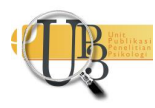


sifat yang positif. Hal ini dibuktikan dengan nilai signifikansi sebesar 0,034. Angka ini lebih kecil dari derajat minimal signifikansi yakni sebesar 0,05. Sehingga dapat disimpulkan bahwa loneliness memiliki pengaruh yang signifikan terhadap job stress. Hal ini sejalan dengan definisi stress kerja menurut Cullen dkk. (1985) dimana adanya ketidaknyamanan psikologis maupun ketegangan yang mengarahkan adanya stressor. Stressor adalah kondisi tuntutan yang berlebihan atau tidak biasa pada seseorang dan dapat menimbulkan ketidaknyamanan psikologis. Kondisi atau tuntutan yang tidak biasa pada karyawan di Indonesia yang melakukan WFH adalah perubahan yang awalnya bekerja secara tim atau kolektif dirubah menjadi bekerja secara mandiri atau sendirian.

Hal ini dapat mengarahkan ketidaknyamanan secara psikologis yang berujung pada stress terhadap pekerjaan yang dilakukan. Bekerja sendirian dapat mengarahkan adanya perbedaan secara objektif (sendirian) dan subjektif (perasaan sendirian) yang mengarahkan pada kesepian (Weiss, 1973). Hal ini berpengaruh pada penilaian setiap individu serta proses psikologis dapat menerima tuntutan sekitarnya sebagai suatu hal yang baik atau buruk, jika penilaian yang akhir terhadap tuntutan tersebut sebagai nilai yang buruk. Loneliness atau kesepian dapat menyebabkan stres kerja, komitmen organisasi yang lemah dan masalah dalam hubungan sosial yang akhirnya dapat memicu keinginan untuk meninggalkan organisasi (Kaymaz dkk. 2014; Cacioppo dkk., 2006; Rizkiyani \& Saragih, 2012).

Perubahan cara kerja dengan pengaturan Work from Home yang dimana seorang pekerja memenuhi tanggung jawab penting dari pekerjaannya dan diharuskan tetap dirumah, dan menggunakan teknologi informasi dan komunikasi atau (ICT). Adanya Covid-19 yang mengharuskan pekerja melakukan WFH telah mengubah rutinitas kerja normal yang menyebabkan percepatan tren yang sudah berlangsung dan melibatkan migrasi pekerjaan ke online atau lingkungan virtual (Kniffin dkk., 2021), hal ini telah membuat banyak pekerjaan mungkin dilakukan lebih mandiri dan menyebabkan sedikitnya pekerjaan yang dilakukan secara tim atau kolektif (Sarpkaya, 2014). Sedikitnya pekerjaan yang dapat dilakukan secara tim atau kolektif mengarahkan perilaku kolektif seseorang berkurang dan mengarah pada individualisme dalam menyeleseikan tugas-tugas pekerjaannya. Ketika budaya kolektivis merupakan budaya bekerja di Indonesia yang dimana banyaknya tugas atau pekerjaan terbiasa dilakukan dengan tim ataupun secara kolektif tidak dapat dilakukan lagi, dikarenakan adanya peraturan WFH yang dimana tugas pekerjaan harus diselseikan secara mandiri atau secara individu selama periode pandemi, dapat memunculkan adanya perasaan sendirian atau bekerja sendiri yang dapat mengarahkan pada perasaan kesepian. Hal ini sesuai dengan Sonderby \& Wagoner (2013), bahwa budaya kolektif memiliki harapan yang lebih tinggi terhadap interaksi sosial dan karenanya akan merasakan diri mereka sendiri menjadi lebih kesepian jika harapan ini tidak terpenuhi.

Kesepian didefiniskan sebagai kurangnya ikatan sosial yang dirasakan atau perasaan subjektif seseorang tentang kurangnya ikatan sosial (Weiss, 1973). Bekerja secara WFH meningkatkan adanya perasaan kesepian dengan terbatasnya interaksi sosial dengan rekan kerja dikarenakan intensitas untuk bertemu, bertatap muka secara langsung berkurang. hal ini dapat mengarahkan pada berkurangnya ikatan sosial yang dirasakan seseorang yang dapat memicu kesepian. Selain itu karyawan dengan budaya kolektif yang dengan adanya WFH dipaksakan untuk bekerja sendirian atau tuntutan untuk bekerja menyeleseikan tugas pekerjaan secara individu dapat mengarahkan adanya stress kerja atau job stress dikarenakan adanya beban kerja atau tuntutan pekerjaan yang harus diselseikan secara mandiri.

Pada hasil di atas dapat dilihat pula nilai $\mathrm{R}^{2}$ sebesar 0,042. Dari angka tersebut dapat dikatakan bahwa variabel independen mampu menyumbang sebesar $4,2 \%$ terhadap job stress. Kontribusi tersebut dapat dikatakan tidak terlalu besar meskipun tetap memberikan pengaruh yang signifikan. Pengaruh yang positif berarti apabila tingkat kesepian meningkat maka job stress akan meningkat. Pengaruh 4,2\% 
terhadap job stress dikarenakan presentase partisipan yang menjawab dengan kriteria pernah melakukan WFH lebih banyak dibandingkan yang sedang melakukan WFH atau adanya ketidak proposional jumlah partisipan, partisipan yang pernah melakukan WFH bekerja kembali secara offline, hal ini berpengaruh pada tingkat kesepian partisipan dan berpengaruh terhadap job stress.

Dalam penelitiannya, Toscano \& Zappalà (2020) mengemukakan bahwa kurangnya interaksi tatap muka secara langsung dengan rekan kerja merupakan salah satu perbedaan utama saat bekerja di waktu biasanya dengan WFH saat ini dan berkomunikasi secara virtual menyebabkan adanya sosial isolasi dan kesepian di masa pandemi covid-19, hubungan kesepian saat ini dengan tingkat stress dan depresi yang tinggi. Pada literatur ini juga berhipotesis bahwa isolasi dan stress dapat diamati dengan kaitannya kehidupan kerja atau hal ini juga disebut sebagai stress kerja, adanya kondisi isolasi ini berhubungan dengan persepsi stress yang lebih besar terhadap pekerjaan. Hasil kedua dari literatur ini terkait dengan hubungan yang kuat antara isolasi sosial dan stress, menunjukkan bahwa pengalaman subjektif perasaan jauh dari rekan kerja tidak hanya menurunkan kepuasan kerja atau job satisfaction, tetapi juga menentukan kondisi stress bagi mereka yang bekerja di rumah selama pandemi (Toscano \& Zappalà 2020).

Selanjutnya penulis melakukan analisis tambahan pada dimensi-dimensi loneliness yang dapat berpengaruh terhadap job stress. Variabel loneliness memiliki dua dimensi, yaitu isolasi emosional dan isolasi sosial. Dimensi dari variabel loneliness yang pertama adalah isolasi emosional. Dalam penelitian ini, isolasi emosional memberikan pengaruh yang signifikan terhadap job stress. Hal ini sesuai dengan definisi isolasi emosional yang merupakan ketidakhadiran yang dirasakan dari kedekatan emosional, sedangkan isolasi sosial dihasilkan dari isolasi relasional yaitu tidak adanya hubungan integratif sosial atau jejaring sosial yang menarik (Weiss, 1973). WFH secara tidak langsung membatasi adanya pertemuan fisik secara langsung dengan rekan kerja yang mengarahkan pada adanya ketidakhadiran yang dirasakan dari kedekatan emosional. Hal ini seperti tidak bisa bertemunya karyawan dengan rekan kerjanya, tidak dapat berbagi cerita secara langsung dengan rekan kerjanya, dan apabila dilakukan dengan jangka waktu yang lama dapat mengurangi kedekatan emosional dengan rekan kerjanya. Sedangkan dimensi isolasi sosial lebih tidak berpengaruh signifikan hal ini dikarenakan bukan tidak adanya hubungan integratif atau jejaring sosial yang menarik akan tetapi adanya pemisahan secara emosional karyawan.

\section{SIMPULAN}

Berdasarkan temuan penelitian, maka dapat ditarik kesimpulan bahwa terdapat pengaruh loneliness terhadap job stress selama WFH di masa pandemi Covid-19. Hasil tersebut menyatakan bahwa $\mathrm{H}_{\mathrm{a}}$ dalam penelitian ini diterima. Dapat disimpulkan bahwa dengan adanya isolasi yang disebabkan oleh perubahan pengaturan kerja yaitu work from home di masa pandemi menyebabkan interaksi secara langsung dengan rekan kerja menjadi terbatas. Dan mengarahkan pada kesendirian yang mengakibatkan beberapa dampak negatif diantaranya stress pada pekerjaan atau stress kerja.

Saran yang dapat diberikan bagi penelitian selanjutnya adalah dengan tidak hanya menggunakan satu variabel prediktor, sehingga nantinya dapat dijadikan pembanding untuk mengetahui nilai besaran pengaruh variabel prediktor lain terhadap variabel stress kerja.

Adanya penelitian ini diharapkan mampu memberikan kontribusi untuk karyawan yang melakukan work from home untuk memenuhi social needs agar tetap terhubung dengan rekan kerja untuk menghindari rasa kesendirian dan dapat menyebabkan dampak negatif seperti adanya stress kerja. Jika 
dirasa bekerja dari rumah menjadi beban tersendiri maka disarankan untuk meminta dukungan dari keluarga, teman, dan tetap terhubung dengan dunia sosial untuk menghindari dampak-dampak negatif tersebut. Selain itu untuk mengurangi kecemasan yang muncul terkait tugas atau tuntutan pekerjaan disarankan karyawan melakukan komunikasi yang baik dengan rekan kerja, dan untuk atasan dapat memberikan kesempatan kepada bawahan untuk menyampaikan kendala terhadap tugas atau pekerjaanya. Dan untuk karyawan dapat mengendalikan pekerjaan yang melebihi kemampuan dan kapasitas kerja dengan menyeleseikan tugas secara bertahap, pegawai dapat menyampaikan kendalakendala tugas atau pekerjaan yang dapat mengganggu kesehatan fisik maupun mental kepada kepala bidang atau dinas, pegawai dapat menciptakan budaya saling memberi motivasi dalam bentuk lisan dan bantuan dalam pekerjaan.

Mengingat pandemi Covid-19 telah memberikan dampak yang cukup berpengaruh bagi karyawan maka penelitian ini dapat dijadikan sebuah pertimbangan untuk perusahaan agar dapat menyediakan program Employee Assistance Program (EAP). Program tersebut dapat berperan efektif untuk dapat menanggulangi kesendirian dan stres kerja pada karyawan, perusahaan juga disarankan untuk membuat program pengembangan karyawan secara virtual, seperti pelatihan manajamen stres.

\section{UCAPAN TERIMAKASIH}

Penulis berterimakasih kepada Bapak dan orang-orang terdekat penulis yang telah memberikan dukungan sehingga penelitian ini dapat terselesaikan dengan baik.

\section{DEKLARASI POTENSI TERJADINYA KONFLIK KEPENTINGAN}

Septa Ayu Trisnasari dan Dimas Aryo Wicaksono tidak bekerja, menjadi konsultan, memiliki saham, atau menerima dana dari perusahaan atau organisasi manapun yang mungkin akan mengambil untung dari diterbitkannya naskah ini.

\section{PUSTAKA ACUAN}

Azhar, F. (2021). Determinan Stres Kerja pada Aparatur Sipil Negara Dinas Pendidikan Kota Cilegon Saat Work From Home di Era Pandemi COVID-19 Tahun 2020. Media Penelitian dan Pengembangan Kesehatan, 31(1), 8.

Cacioppo, J. T., Hawkley, L. C., Ernst, J. M., Burleson, M., Berntson, G. G., Nouriani, B., \& Spiegel, D. (2006). Loneliness within a nomological net: An evolutionary perspective. Journal of Research in Personality, 40(6), 1054-1085. https://doi.org/10.1016/j.jrp.2005.11.007

Cullen, F. T., Link, B. G., Wolfe, N. T., \& Frank, J. (1985). The social dimensions of correctional officer stress. Justice Quarterly, 2(4), 505-533. https://doi.org/10.1080/07418828500088711

Kaymaz, K., Eroğlu, U., \& Sayılar, Y. (2014). Effect of Loneliness at Work on the Employees' Intention to Leave. ISGUC The Journal of Industrial Relations and Human Resources, 16(1), 38-53. https://doi.org/10.4026/1303-2860.2014.0241.x 
Kniffin, K. M., Narayanan, J., Anseel, F., Antonakis, J., Ashford, S. P., Bakker, A. B., Bamberger, P., Bapuji, H., Bhave, D. P., Choi, V. K., Creary, S. J., Demerouti, E., Flynn, F. J., Gelfand, M. J., Greer, L., Johns, G., Kesebir, S., Klein, P. G., Lee, S. Y., ... van Vugt, M. (2021). COVID-19 and the Workplace: Implications, Issues, and Insights for Future Research and Action. 44.

Lykes, V. A., \& Kemmelmeier, M. (2014). What Predicts Loneliness? Cultural Difference Between Individualistic and Collectivistic Societies in Europe. Journal of Cross-Cultural Psychology, 45(3), 468-490. https://doi.org/10.1177/0022022113509881

Mustajab, D., Bauw, A., Rasyid, A., Irawan, A., Akbar, M. A., \& Hamid, M. A. (2020). Working From Home Phenomenon As an Effort to Prevent COVID-19 Attacks and Its Impacts on Work Productivity. TIJAB (The International Journal of Applied Business), 4(1), 13. https://doi.org/10.20473/tijab.V4.I1.2020.13-21

Nakrošienè, A., Bučiūnienè, I., \& Goštautaitė, B. (2019). Working from home: Characteristics and outcomes of telework. International Journal of Manpower, 40(1), 87-101. https://doi.org/10.1108/IJM-07-2017-0172

Ozcelik, H., Beetz, A., \& Barsade, S. (n.d.). UNDERSTANDING AN EPIDEMIC DURING A PANDEMIC: A RELOOK AT WORK LONELINESS IN TIME OF COVID-19. 6.

Parker, D. F., \& DeCotiis, T. A. (1983). Organizational determinants of job stress. Organizational Behavior and Human Performance, 32(2), 160-177. https://doi.org/10.1016/0030-5073(83)90145-9

Ramesh, A., \& Gelfand, M. J. (2010). Will they stay or will they go? The role of job embeddedness in predicting turnover in individualistic and collectivistic cultures. Journal of Applied Psychology, 95(5), 807-823. https://doi.org/10.1037/a0019464

Rizkiyani, D., \& Saragih, S. R. (2012). STRESS KERJA DAN MOTIVASI KERJA PADA PETUGAS LEMBAGA PERMASYARAKATAN. Jurnal Manajemen Maranatha, 12(1).

Russell, D. W. (1996). UCLA Loneliness Scale (Version 3): Reliability, Validity, and Factor Structure. Journal of Personality Assessment, 66(1), 20-40. https://doi.org/10.1207/s15327752jpa6601_2

Sarpkaya, P.Y. (2014). The effects of principals' loneliness in the workplace on their self-performance. Educational Research and Reviews, 9(20), 967-974. https://doi.org/10.5897/ERR2014.1847

Sonderby, L., \& Wagoner, B. (2013). LONELINESS: AN INTEGRATIVE APPROACH. 3, 29.

Toscano, F., \& Zappalà, S. (2020). Social Isolation and Stress as Predictors of Productivity Perception and Remote Work Satisfaction during the COVID-19 Pandemic: The Role of Concern about the Virus in a Moderated Double Mediation. Sustainability, 12(23), 9804. https://doi.org/10.3390/su12239804

Weiss, R. S. (1973). Loneliness: The experience of emotional and social isolation. (pp. xxii, 236). The MIT Press. 